\title{
IS THERE ECOLOGICAL ADAPTATION IN COCONUT NURSERY SEEDLINGS STAGE? A PRELIMINARY INVESTIGATION
}

\author{
R R A Peries and J M D T Everard
}

Coconut Research Institute, Lunuwila, Sri Lanka

\begin{abstract}
Seedlings were raised in three nurseries representing different agro-ecological regions, to test whether growing seedlings exhibited adaptation to a particular environment. Seed nuts were also selected from agro-ecologically different regions. The $T \times T$ seed nuts from the Isolated coconut seed garden showed a faster rate of germination at all sites compared to Moorock seed nuts (from the North Western region) or Dehigahalande seed nuts (from the Southern region). The vigor of seedlings (a qualitative assessment based on the number of vigorous seedlings selected) was enhanced by a good soil water supply during the early nursery stages combined with a higher level of solar-radiation at the nursery site. There was no interaction between the source of seed nut and site of nursery indicating the absence of manifestation of ecological adaptation at the seedling nursery. The quality of the seedlings was enhanced by adequate soil water and high level of solar radiation on the nursery beds. The subsequent performance. of these seedlings would have followed up after field planting to confirm the assumptions on adaptation discussed.
\end{abstract}

\section{INTRODUCTION}

The national coconut planting programme in Sri Lanka has targeted to replant/ underplant $2 \%$ of the area currently under coconut which amounts to approximately 9000 ha annually. This requires the selection of about 2.3 million seed nuts (Liyanage, 1983). In 1990, 2.5 million seedlings were raised in coconut nurseries to be distributed throughout the country. While the seed gardens were able to supply only $12 \%$ of this requirement (Peries, 1990) the balance was supplied through elite palms in selected estates, referred to as "plus palms" (Liyanage, 1983). These palms were selected for their higher nut and copra yield compared to the mean yield of their population.

Seed nut sources as well the seed gardens are located quite far from the nurseries where seedlings are raised, often in different agro-ecological regions. The observation had been made that seeds from a particular estate or seed garden had a higher percentage of success in seedling production when compared to others at a given nursery. 
Time taken for germination of seed nuts and early seedling vigour are important determinants of the performance of the adult palm (Liyanage, 1957). Early germinating seedlings give rise to palms that flower early and produce greater yield of nuts and copra (Liyanage and Abeywardene, 1957). If ecological adaptation can be identified as an important trait at the seedling nursery, it could be useful in screening material suited to specific agro-ecological conditions.

There is a large body of circumstantial evidence that palm populations present in a particular region are adapted to many pest, disease, soil and environmental factors (Foale, 1991). There is no information however, if specific ecological adaptation has been shown by nursery seedlings even though it may be present in seed palm populations, as seen by their survival capability under sub-optimal environmental conditions (Peries, 1994). As a first step, it was therefore considered important to ascertain if such adaptation is shown by germinating seed nuts and young seedlings in the nursery.

\section{MATERIALS AND METHODS}

A nursery experiment was conducted at three nurseries in different agroecological regions namely Attavillu (dry zone) and Bandirippuwa (wet, intermediate zone) both in the North Western region and Medamulana (dry, intermediate zone) in the Southern region. Seed nuts were used from three different sources, namely the Isolated Seed Garden (ISG) Ambakelle (i.e. $\mathrm{T} \times \mathrm{T}$ material), Moorock estate, Mawathagama (plus palm subjected to a high selection pressure), and Dehigahalande estate, Ambalantota (plus palm subjected to a low selection pressure). The agroecological conditions of these different regions are summarized in Table 1.

The experiment was conducted from June 1990 to February 1991. All seed nuts for the experiment were collected from the third pick (May/June) of 1990. Random samples of 900 seed nuts were obtained from each source and distributed to the three nursery sites. The nuts were stored for two weeks under shade to obtain a similar level of maturity at laying (Nuce de Lamothe and Wuidart, 1982). The nuts were sown in randomized blocks with three replicates. Each bed had 100 seed nuts laid in five rows of 20 seed nuts each.

The management of the seed beds at all sites was as stipulated in advisory circular (CRI, 1971), with minor refinements (Mahindapala and Pinto, 1991). The seed nuts were dipped in a $10 \%$ solution of Aldrin prior to laying to prevent termite attack. The beds were mulched with dry coconut fronds and irrigated once in three days during dry weather (Peries, 1984). Manual weeding was carried out at the onset of the dry weather.

Seed germination was recorded once in two weeks starting from the tenth week after laying. At the end of $\mathbf{2 0}$ weeks, all non-germinated nuts and late germinating nuts were removed from beds. The growth parameters such as girth (measured at the base of the plant), height (measured from the seednut to the tip of the youngest fullyopened leaf), total number of leaves produced and length and breadth of the youngest 
fully-open leaf (length was measured from the base of the leaf to the tip and breadth was measured at the broadest point on the leaf) were measured at 28 weeks from seed laying. Leaf width: length ratio was compared to see if cultivars or ecotypes showed any specific morphological adaptation in fitting into a specific environment. In the Philippines seedlings selected for a low width : length are said to survive better under water - limiting environments (G.A. Santos, pers. comm.)

Table 1 Summary of weather conditions during the experiment at the three nurseries.

\begin{tabular}{lllllll} 
Nurseries & $\begin{array}{l}\text { Rainfall } \\
\text { (mm) } \\
\vdots\end{array}$ & $\begin{array}{l}\text { Number } \\
\text { rainy days }\end{array}$ & $\begin{array}{l}\text { Relative } \\
\text { humidity (\%) }\end{array}$ & $\begin{array}{l}\text { Sunshine } \\
\text { hours/day }\end{array}$ & $\begin{array}{l}\text { Evaporation } \\
\text { mm/day }\end{array}$ & $\begin{array}{l}\text { Rain free } \\
\text { weeks }\end{array}$ \\
\hline
\end{tabular}

\section{Period after}

sowing (weeks)

Bandirippuwa

\begin{tabular}{lllllll}
$1-20$ & 343.4 & 34 & 75.9 & 7.2 & 4.6 & $8,9,10,12,13$ \\
$21-28$ & 901.8 & 30 & 78 & 6.2 & 3.5 & 27 \\
$29-39$ & 147.1 & 16 & 70.5 & 7.9 & 4.5 & $34,36,37,38$ \\
\hline
\end{tabular}

Attavillu

\begin{tabular}{|c|c|c|c|c|c|c|}
\hline $\begin{array}{l}1-20 \\
16,17,18\end{array}$ & $307.4^{\circ}$ & 11 & 73.6 & 6.5 & 5.6 & $1-14$ and \\
\hline $21-28$ & 516.8 & 25 & 84.3 & 5.6 & $* *$ & -- \\
\hline $29-39$ & 121.0 & 18 & 85.8 & 6.9 & ** & $31,34,36,37$ \\
\hline
\end{tabular}

Medamulana

\begin{tabular}{lllllll}
$1-20$ & $275.1^{*}$ & 31 & 70.3 & 7.8 & 5.8 & $\begin{array}{l}7,9,11,12,13, \\
\end{array}$ \\
$21-28$ & 454.4 & 32 & 84.2 & 6.0 & 3.7 & $14,16,17,18$ \\
$29-39$ & 175.7 & 13 & 82.2 & 7.6 & 4.1 & $34,35,37,38$ \\
\hline
\end{tabular}

* data not available

\section{RESULTS AND DISCUSSION}

The weather conditions during the experiment in the three nurseries (Table 1) indicate that there were varying number of rain free weeks after laying seednuts at the different nursery sites. Attavillu appeared to be the driest with weeks 1 to 14 and weeks 16-18 being completely rain free. There was some initial rain at Medamulana but beginning from the 7th week, there were several rain free weeks with little effective rainfall during weeks $8(7.8 \mathrm{~mm}), 10(1.7 \mathrm{~mm})$ and $15(10.8 \mathrm{~mm})$. Beyond the 20 - week stage all nurseries bad a very favourable rainfall distribution.

A seed nut was considered to have germinated when the plumule emerged out of the husk (Thomas, 1978). When observations were pooled across all nurseries, the nuts from ISG took significantly less time (112 days) to germinate compared to nuts Moorock (119 days) or Dehigahalande (125 days) (Table 2). 
Table 2 The mean number of days taken for germination by seed coconuts from different sources, Amabakelle (ISG), Dehigahalande (Ambalantota) and Morook (Mawathagama) estates at the different nursery sites

\begin{tabular}{llc}
\hline $\begin{array}{l}\text { Source of } \\
\text { seed nuts }\end{array}$ & $\begin{array}{l}\text { Nursery } \\
\text { site }\end{array}$ & $\begin{array}{c}\text { Mean number of days } \\
\text { for germination }\end{array}$ \\
\hline Ambakelle & $\begin{array}{l}\text { Attavillu } \\
\text { Bandirippuwa } \\
\text { Medamulana }\end{array}$ & 115 \\
Dehigahalande & Attavillu & 114 \\
& Bandirippuwa & 108 \\
& Medamulana & 125 \\
Moorock & & 125 \\
& Attavillu & 123 \\
& Bandirippuwa & 123 \\
Source mean & Medamulana & 119 \\
& Ambakelle & 115 \\
& Dehigahalande & 112.2 \\
Site mean & Moorock & 124.5 \\
& & 119.1 \\
& Attavillu & 121.1 \\
& Bandirippuwa & 119.4 \\
& Medamulana & 115.3 \\
& & 1.25 \\
& Standard Error & $18 \%$ \\
LSD (P<0.05) & Between source, 3.25 & Between site, 3.25 \\
& Source x site interaction, not significant \\
\hline & & \\
& &
\end{tabular}

The difference between Moorock and Dehigahalande was also significant. When sites were compared, Medamulana was significantly superior (115 days) to Bandirippuwa (119 days) and Attavillu (121 days). The available moisture on the seed bed has been found to be the critical factor facilitating germination (Wuidart, 1981). However, with supplementary irrigation provided during rain-free periods, moisture did not seem to be the critical factor enhancing germination in this instance. It would appear that the greater duration of sunshine (and therefore, radiation intensity) at Medamulana provided the right temperature for rapid seed germination. The low relative humidity at Medamulana (70\%) compared to Bandirippuwa (76\%) and Attavillu (74\%) supports the argument that during the early period of seed germination, seed beds at Medamulana were dryer than that in the other two locations (Table 1). 
At 12 weeks, the overall germination of Ambakelle seed nuts reached $22 \%$ (Table 3) which was significantly higher than that recorded by Moorock and Dehigahalande seed nuts (12\% and 7\% respectively). The difference between the latter two values was also significant. At 16 weeks the germination percentage of Ambakelle seed nuts reached $77 \%$ which was again significantly higher than the corresponding values for Moorock and Dehigahalande (69\% and $64 \%$ respectively). The rate of germination of Ambakelle seed nuts was even superior to values reported for the tall variety elsewhere (Harries, 1983; Wuidart, 1981). This was expected as the seed palms at Ambakelle are crosses between selected parents which have gone through several stages of further selection prior to being used as seed parents. This parent population also has a very high yield potential (approximately 25,000 nuts/ha) under a satisfactory rainfall distribution (Liyanage et al.; 1988). The relatively improved performance of Moorock seèd compared to Dehigahalande seed could also be attributed to the rigorous selection procedure imposed on the seed parents. There had been palm selection to four generations in Moorock estate based on nut characters (Wickramaratne, 1987). Dehigahalande seed comes from plus palms and has undergone the least selection pressure compared to the other two sources of seed.

By 20 weeks seed nuts from all sources reached a similar level of germination (approx. 83\%). The site-wise data indicated that at 12 weeks overall germination at Bandirippuwa and Medamulana was similar (15\%) and was significantly greater than that at Attavillu (11\%). This may be related to the fact that weeks 1 to 14 after laying in Attavillu were completely rain free (Table 1). At 16 weeks the germination percentage was similar at all sites but at 20 weeks the value was significantly greater at Attavillu (88\%) compared to Bandirippuwa (83\%) and Medamulana (79\%).

Girth of seedlings from all sources varied in a similar fashion at all the sites (Table 4). However, the overall girth was significantly higher at the Medamulana site $(13.1 \mathrm{~cm})$ when compared to Attavillu $(11.8 \mathrm{~cm})$ and Bandirippuwa (10.6). The height of Ambakelle seedlings $(93.2 \mathrm{~cm})$ was significantly superior to Dehigahalande $(86 \mathrm{~cm})$ and Moorock $(85.2 \mathrm{~cm})$ seedlings at alt sites. The overall height of seedlings was significantly higher at Attavillu $(95 \mathrm{~cm})$ than at Medamulana $(88.8 \mathrm{~cm})$ and Bandirippuwa $(80.6 \mathrm{~cm})$.

The difference between the latter two was also significant. The leaf number and the width : length ratio was similar amongst all seedlings. The overall observations on growth parameters revealed that there was no significant source $\mathrm{x}$ site interaction in the expression of seedling vigour.

The percentage of vigorous seedlings selected after 28 weeks for planting was taken as a measure of success of the three types of seed at the three nurseries. Table 5 summarizes the final output of seedlings at the three sites. The level of success achieved by seed nuts from the three sources was very similar at the three nursery sites. However, the overall production of vigorous and plantable seedlings at Attavillu (87\%) was significantly higher than at Bandirippuwa (75\%) and Medamulana (74\%). 
Table 3 Temporal change in germination of seed coconuts from different sources at Attavillu (Puttalam), Bandirippuwa and Medamulana Weeraketiya) nursery sites

\begin{tabular}{|c|c|c|c|c|}
\hline $\begin{array}{l}\text { Nursery } \\
\text { site }\end{array}$ & $\begin{array}{l}\text { Source of } \\
\text { seed nut }\end{array}$ & $\begin{array}{l}\text { Percent } \\
12 w k\end{array}$ & $\begin{array}{l}\text { germin } \\
\text { 16wk }\end{array}$ & $\begin{array}{l}\text { ation at } \\
20 w k\end{array}$ \\
\hline \multirow[t]{3}{*}{ Attavillu } & Dehigahalande & 7 & 65 & 87 \\
\hline & Ambakelle & 18 & 81 & 90 \\
\hline & Moorock & 8 & 71 & 87 \\
\hline \multirow[t]{3}{*}{ Bandirippuwa } & Dehigahalande & 7 & 67 & 87 \\
\hline & Ambakelle & 23 & 72 & 82 \\
\hline & Moorock & 15 & 65 & 79 \\
\hline \multirow[t]{3}{*}{ Medamulana } & Dehigahalande & 6 & 61 & 76 \\
\hline & Ambakelle & 27 & 77 & 82 \\
\hline & Moorock & 13 & 68 & 80 \\
\hline \multirow[t]{3}{*}{ Source mean } & Dehigahalande & 6.8 & 64.2 & 83.2 \\
\hline & Ambakelle & 22.2 & 76.8 & 84.8 \\
\hline & Moorock & 12.2 & 69 & 82.2 \\
\hline \multirow[t]{3}{*}{ Site mean } & Attavillu & 10.8 & 72.3 & 88.1 \\
\hline & Bandirippuwa & 15.3 & 68 & 82.8 \\
\hline & Medamulana & 15.6 & 69.7 & 79.3 \\
\hline \multirow[t]{3}{*}{ LSD $(P<0.05)$} & Between source & 3.5 & 6.63 & ns \\
\hline & Between site & 3.5 & ns & 5.01 \\
\hline & Site $\mathrm{x}$ source & ns & ns & ns \\
\hline
\end{tabular}

ns, not significant

This was perhaps a manifestation of the effect of high atmospheric relative humidity $(86 \%)$ during the $29-30$ week period compared to Bandirippuwa (71 \%) and Medamulana ( $83 \%)$. The total dry matter production per unit of water transpired (i.e. transpiration efficiency) in the growing seedling is higher under high relative humidity (Fisher, 1981). Subsequent growth of seedlings following germination is dependent upon the availability of adequate water in the soil and also the level of radiation to facilitate photosynthesis and transpiration. As atmospheric relative humidity decreases and evaporation.demand increases, the productive process of the seedlings is slowed down. The favourable environment at Attavillu may have been further enhanced by the loose and friable sandy soil at the site (also at Bandirippuwa) compared to the heavier soil at Medamulana facilitating better utilization of soil nutrients by growing seedlings. Similar observations have been made by Remison and Iremiren (1990) where nutrient uptake in coconut seedlings was found to be higher in sandy maritime soils than in the heavier forest soils. 
Table 4 Parameters of seedling vigour at the three nursery sites for seedlings raised from different sources of seed nut

\begin{tabular}{|c|c|c|c|c|c|}
\hline \multirow{2}{*}{$\begin{array}{l}\text { Nursery } \\
\text { site }\end{array}$} & \multirow{2}{*}{$\begin{array}{l}\text { Source of } \\
\text { seed nut }\end{array}$} & \multicolumn{4}{|c|}{ Growth measurements at 28 weeks after seed laying } \\
\hline & & Girth & Height & Leaf No. & W/L' \\
\hline \multirow[t]{3}{*}{ Attavillu } & Dehigahalande & 11.7 & 92.7 & 3.8 & 0.24 \\
\hline & Ambakelle & 11.9 & 98.3 & 4.1 & 0.24 \\
\hline & Moorock & 11.7 & 94.0 & 4.0 & 0.24 \\
\hline \multirow[t]{3}{*}{ Bandirippuwa } & Dehigahalande & 10.3 & 79.0 & 3.6 & 0.21 \\
\hline & Ambakelle & 11.2 & 87.3 & 3.8 & 0.23 \\
\hline & Moorock & 10.3 & 75.5 & 3.7 & 0.23 \\
\hline \multirow[t]{3}{*}{ Medamulana } & Dehigahalande & 12.4 & 86.3 & 3.5 & 0.24 \\
\hline & Ambạkelle & 13.3 & 94.0 & 3.8 & 0.24 \\
\hline & Moorock & 13.5 & 86.1 & 3.8 & 0.24 \\
\hline \multirow[t]{3}{*}{ Source mean } & Dehigahalande & 11.4 & 86.0 & 3.7 & 0.23 \\
\hline & Ambạkelle & 12.2 & 93.2 & 3.9 & 0.24 \\
\hline & Mooriock & 11.9 & 85.2 & 3.8 & 0.24 \\
\hline \multirow[t]{3}{*}{ Site mean } & Attavillu & 11.8 & 95.0 & 4.0 & 0.24 \\
\hline & Bandirippuwa & 10.6 & 80.6 & 3.7 & 0.23 \\
\hline & Medamulana & 13.1 & 88.8 & 3.7 & 0.24 \\
\hline \multirow[t]{3}{*}{ LSD $(P<0.05)$} & Between source & ns & 3.93 & ns & \\
\hline & Between site & 0.80 & 3.93 & ns & ns \\
\hline & Site $x$ source & ns & ns & ns & ns \\
\hline
\end{tabular}

'Width : length ratio ns, not significant

The absence of any source $x$ site interactions indicate the non-existence of physiological adaptation in the different sources of seed nuts when grown in selected nurseries. Whatever differences in the rate of germination or seedling characters that were observed appeared to be similar across different agro-ecological regions, perhaps suggesting the absence of much variation between populations from which the seed was selected.

It is also possible that such adaptation might manifest in an adult palm rather than in a nursery seedling, as the physiological mechanisms and its genetic controls are yet developing in the nursery seedling. Nurturing of a nursery seedling is therefore of utmost value in helping it to manifest its adaptation at the adult palm stage. Evidence has been presented of specific adaptation to soil and rainfall patterns evolving naturally in coconut populations in many countries (Harries, 1990; Foale, 1991). 
Some past data on seedling production and issues at the Medamulana and Attavillu nurseries were collated for comparison in the present study (Table 6). With different sources of seed nuts, the percentage of seedlings issued had ranged from 59 to 69.5 . The lowest $(59 \%)$ had been .achieved with CRIC 65 (D x T) which are small in size and contain less nut water (Liyanage, 1958) than the tall cultivar. In an area of high solar radiation (Attavillu) lack of adequate soil water would have been a major factor lowering the quality and therefore the quantity of plantable/vigorous seedlings. In general, the values in Table 6 are all lower than those obtained in the present study. These observations and the findings of the present study would have practical implications in the successful management of coconut seedling nurseries. Lack of proper after-care of nursery seed beds could be a major reason for poor germination and subsequent growth of seedlings. In the current study, where the management of seed beds was maintained at optimum level, very little difference was obtained between sites except those due to the superiority of the source of nuts.

Table 5 Vigorous and plantable seedlings selected at the three nurseries afier 28 weeks from laying of seed nuts from different sources

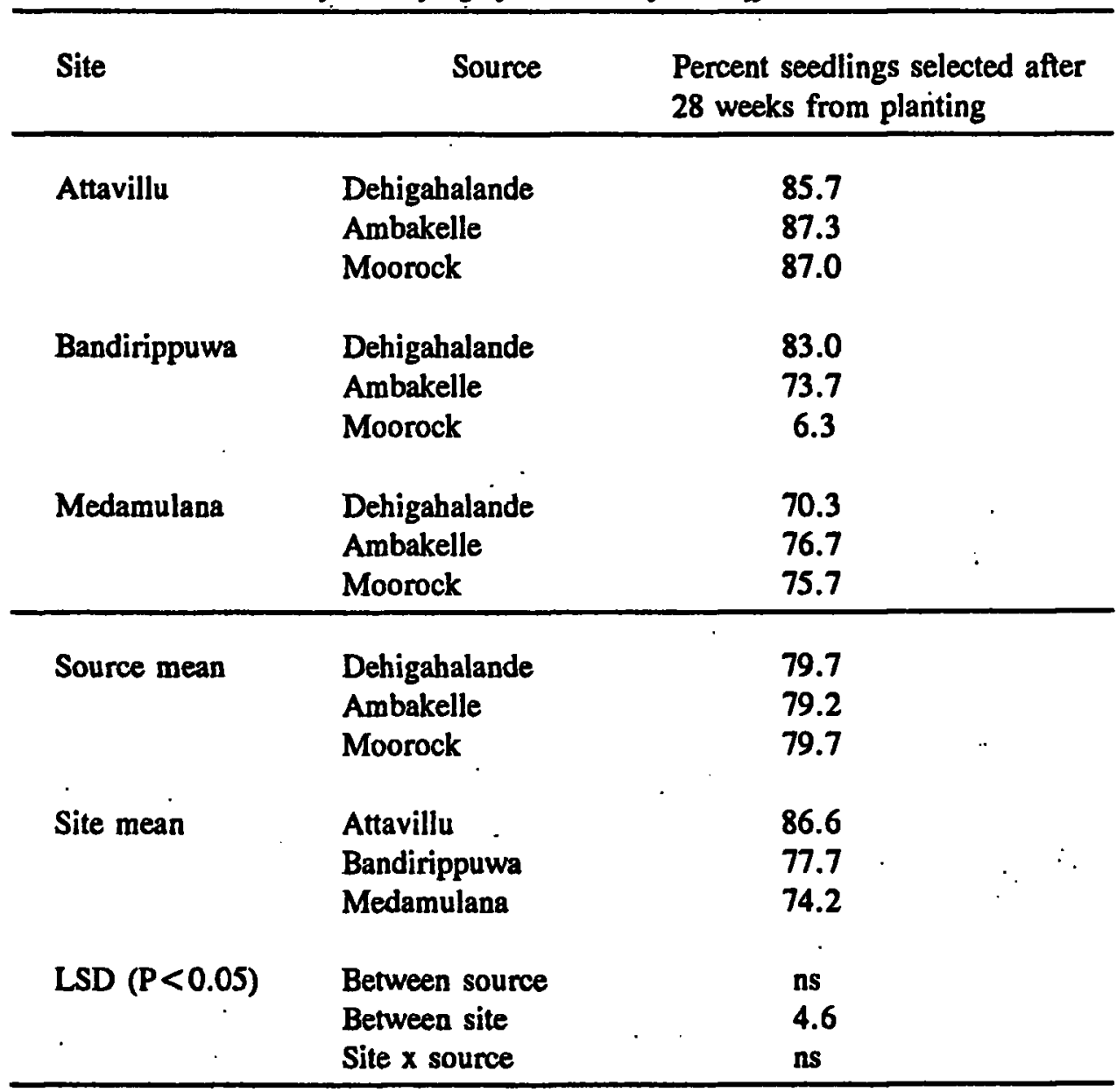

ns, not significant 
Table 6 Seedling production at Attavillu and Medamulana nurseries during the period 1987-1990

\begin{tabular}{lr|lll}
\hline Nursery & Period & Variety/ & Number of \\
& & & $\begin{array}{l}\text { cultivar } \\
\text { nuts laid }\end{array}$ & $\begin{array}{l}\text { Percent } \\
\text { seedlings } \\
\text { issued }\end{array}$ \\
\hline Medamulana & $1989-90$ & CRIC 60 & 19000 & 69.5 \\
& $1989-90$ & Dehigahalande & 52350 & 61.9 \\
& $1989-90$ & Other & 20700 & 60.4 \\
& $1987-89$ & CRIC 60 & 88500 & 66.8 \\
Attavillu & $1987-89$ & CRIC 65 & 27000 & 59.0 \\
\hline
\end{tabular}

Germination can be adversely affected by lack of water in the seed nut which is very likely to be aggravated in the absence of adequate watering (Wuidart, 1984; Peries, 1984). Remison and Mgbeze (1987) observed that the use of a mulch to conserve water in the coconut seed beds led to increased plant height, plant girth and dry matter yield. Thus the provision of adequate water at sites of germination would appear to be of prime importance. While ecological adaptation may be a trait that is manifested in older seedlings and young palms, nursery seedlings would require a stress free environment during their initial period of growth and development to truly manifest their genetic potential.

\section{ACKNOWLEDGEMENTS}

The management of commercial nurseries in Sri Lanka is the responsibility of the Coconut Cultivation Board (CCB). This experiment was conducted in collaboration with the CCB as a result of observations reported from the nurseries located throughout the country. We are thankful to the staff of the Genetics and Plant Breeding Division of Coconut Research Institute and the field staff of the Medamulana and Attavillu nurseries of the CCB for their assistance in the successful conduct of this experiment. The authors also wish to thank Professor U R Sangakkara of the Faculty of Agriculture, University of Peradeniya and Mr D T Mathes, Head of the Biometry Division of CRI for their valuable comments on the manuscript.

\section{REFERENCES}

Anonymous, (1971). Advisory leaflet No 2. Coconut Research Institute, Lunuwila, Sri Lanka.

Fisher, R. A. (1981). Optimizing the use of water and Nitrogen through breeding of crops. Plant and soil 58: 249-78.

Foale, M. A. (1991). Coconut genetic diversity - present knowledge and future research needs. Proceedings of the International workshop on coconut genetic resources, Cipanas, Indonesia, 8 - 11 October, 1991. 
Harries, H.C. (1983). A ten point coconut nursery programme to avoid germination problems. Planter, Kuala Lumpur, 59: 207 - 214.

Harries, H.C. (1990). Malaysian origin for a domestic Cocos nucifera. In P. Bass et al. (eds.) The Plant Diversity Malaysia, pp 351 - 357. P. Kluwer Academic Publishers, Netherlands.

Liyanage, D.V. and Abeywardena, V. (1957). Correlations between, seedling and adult palm characters in coconut. Tropical Agriculturist, CXIII: $325-340$

Liyanage, D.V. (1957). Report of the Botanist. Ceylon Coconut Q.: 21, 22 - 24.

Liyanage, D.V. (1958). Varieties and forms of the coconut palm grown in Ceylon. Ceylon Coconut Review Q. 9: 1 - 10

Liyanage, D.V. (1983). Improvement of coconut and seedling selection. Report No. I of the Consultant on Coconut Breeding, Coconut Development Authority.

Liyanage, D.V.; Wickramaratne, M.R.T. and Jayasekara, C. (1988). Coconut breeding in Sri Lanka: a review. Cocos 6: 1 - 26.

Mahindapala, R. and Pinto J.L.G.J. (1991). Coconut Cultivation, Coconut Research Institute, Sri Lanka, 10 - 12.

Nuce de Lamothe M. de and Wuidart, W. (1982). Observation of vegetative development, flowering and yield characteristics of coconut. Oleagineux, $3: 291$ - 300 .

Peries, R.R.A. (1984). Some observations on the pre-nursery system for raising coconut seedlings. Cocos 2: $10-17$.

Peries, R.R.A. (1990). Report of the Genetics and Plant Breeding Division. In Annual Report of the Coconut Research Institute for 1990, 41-66.

Remison, S.U. and Mgbeze, G. (1987). Competitive effects of weed and beneficial effect of mulching on coconut seedlings. Cocos 5: $19-28$.

Remison, S.U. and Iremiren, G.O. (1990). Effect of salinity on the performance of coconut-seedlings in two contrasting soils. Cocos 8: $33-40$.

Thomas, K.M. (1978). Influence of seed size and planting orientation on the germination and growth of coconut seedlings in the nursery. Indian J. Agric. Sci. 48: 3 - 67 .

Wickramaratne, M.R.T. (1987). Report of the Genetics and Plant Breeding Division. In Annual Report of the Coconut Research Institute for 1987, 51-107.

Wuidart, W. (1981). Production of coconut planting material - Selection of hybrids in the seed-bed. Oleagineux, 36: 497 - 499. 